\title{
電力ケーブルの故障点探査における信号処理による精度改善
}

\author{
正 員 犬塚 博 (静岡大学) \\ 学生員 井上 剛 (静岡大学) \\ 学生員 仲山正樹 (静岡大学) \\ 正 員 松本隆宇 (静岡大学)
}

\section{Accuracy Improvement Using by Signal Processing in the Fault Location for Underground Cable System}

\author{
Hiroshi Inuzuka, Tsuyoshi Inoue, Masaki Nakayama, and Takaie Matsumoto \\ (Shizuoka University)
}

\begin{abstract}
In a fault location system by the current surge detection, the difference time of arrival on the fault current surge is measured at two positions on either side of the fault point. However, a rounding of the wave caused by a frequency characteristic of the power cable degrades the accuracy of the fault location. To improve the accuracy, we use some signal processing method, a frequency compensation, a decision algorithm of a pulse arrival timing form the rounded pulse, and estimation of the surge velocity in the power cable with high accuracy. In the frequency compensation, a digital filter with the inverse of frequency characteristics of this power cable is designed. The rounded surge at the measured point is sharpened by this inverse filter. The velocity of the surge in the power cable is estimated from the measurement of the phase characteristics of the cable. The velocity estimated as mean value of the phase characteristics slope weighted by the frequency spectrum of the surge.

A $1 / 10$ scaled model of $275 \mathrm{kV}$ cross bonded cable system was built for the test of real time fault location system. The relative location errors defined by the ratio of error distance and the location base length are measured at seven artificial fault points, and results of the accuracy estimated from each algorithms. As a result of signal processing the accuracy of the fault location had been improved with the location error within $0.5 \%$.
\end{abstract}

キーワード : 故障点探査、周波数特性、伝搬特性、信号処理、サージ

\section{1.はじめに}

近年、各家庭の電力需要は年々大きくなり、それを担 う電力の輸送は我々の生活にとって必要不可久なもの となっている。そのような電力輸送手段として、地中電 カケープルは益々重要性を增しており、長距離化も進ん できている。このような長距離線路は一般的に重要線路 である場合が多く、事故に際して迅速に事故点检出を行 い早期復旧を行うことができるフォールトトレランス が樫めて重要視される。

電力ケーブルの事故としては絶縁破壊が最大の問題
であるが、これはケーブルの絶縁体中のボイド・暴物・ 架起等を起点として、電界・熱・機械力・環境（水の供 給）等の劣化要因が単独または複合して加わり、部分放 電・電気トリー・水トリーのように実際の局所的な劣化 形態が現れ、これらの局所的劣化が更に進展すると多く の場合トリーイング(treeing)を経て絶縁破壊に至る。そ して、ひとたび絶縁破壊に至ると電力の輸送が断絶する 事態となってしまう。

このようなケーブル線路の事故時には、健全ケーブル と異なる特性インビーダンスを持つ事故点からの反射 


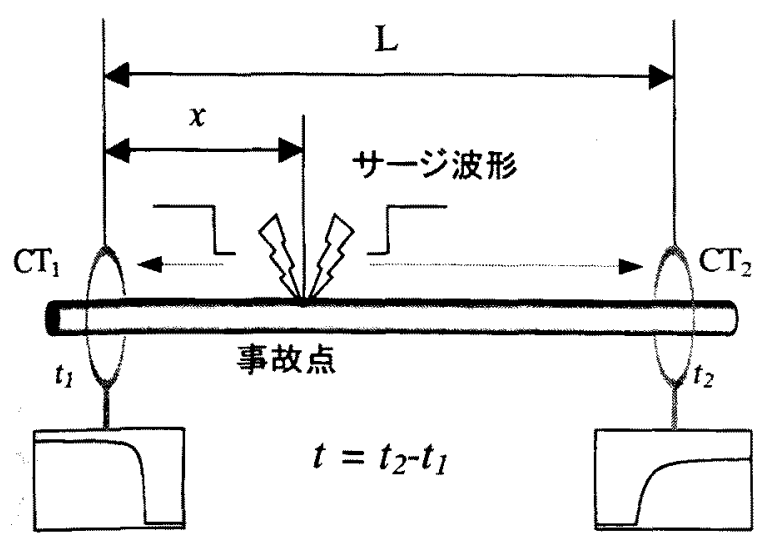

因 1 サージ電流受信型事故点㛟出の原理

Fig. 1 Principal of the fault location by receiving surge-current.

パルスを検出するパルスレーダ法や、ホイートストンブ リッジの応用であるマーレーループ法といった手法で 事故点標定が行われるが(1)、(2)、これらの手法では事 故点の標定までに多くの手間と時間を要してしまう点 が問題であった。

そこで、ケーブル線路に常設した装置により自動的に 事故点が標定できれば、迅速且つ適切な処理を施すこと が出来るという考えを基に、現在、地絡時に発生する急 峻な地絡電流波形の到来時間差を複数点で測定し故障 点の標定を行う電流サージ検出方式が检郡されている (3), (4)。

この方式では、観測点におけるサージ波形の到来時間 をいかに精度良く測定するかが故障点の測定精度に直 結するが、事故点では急峻な波形もケーブル中を伝搬し ていくうちにケーブル自身の周波数特性のために鏠り (5)-(7)、到来時間の決定が困難となってしまうため。

事故点の測定精度が悪化してしまう(3)。

そこで本研究では、ケーブルの周波数特性を测定し、 それを基にサージの変歪の仕方を知ることで、鈍った波 形によ゙のような信号処理を施せばより精度良く事故点 を求めることが出来るかを検討することを目的とする。

論文の構成は以下のようになものである。

まず第 2 章で、本手法による故障点挆査法の原理と錯 つたパルスの到来時刻を決定するいくつかのアルゴリ ズムについて述べる。次に第 3 章ではケーブルの周波数 特性をキャンセルするディジタルフィルタを用いて到 来波形の鈍りを補正し波形の到来点を明確にすること により故障点位置測定精度向上を図る手法を紹介する。 第 4 章では模擬地絡を用いて実際に行った電流サージ 蚞出方式による事故点標定実験の結果を示すと共に、上 記信号処理の効果を検討する。第 5 章では、その結果問 題となったケープル中のパルスの伝搬速度の決定法に ついての考察を述べる。最後に第 6 章で結論を述べる。

\section{2. 電流サージ检出方式}

\section{1 電流サージ検出方式の原理}

図1に電流サージ检出方式による故障点探査法の原 理図を示す。ケーブルが絶縁破壊等により短絡事故を起 こした場合、故障点では図 2 に示すような急峻な地絡電 流波形が生じる。これは人工欠陷を作成した $22 \mathrm{kV}$ 級 CVケーブルの地絡実験で得られた波形である。この波 形は事故点から等速度で楾路中を両側八伝搬するので、 このサージ波形を複数の点に設置された電流センサ CT1,CT2 で捕らえる。各々の電流センサで检出された サージの到来時間差 $t$ と、既知の犆である線路長 $L$ 、ケ 一プル中のサージの伝搬速度 v䎞用いてセンサから事 故点までの距離 $x$ 堂、次式を用いて求めることが出来る。

$$
x=\frac{L-v t}{2}
$$

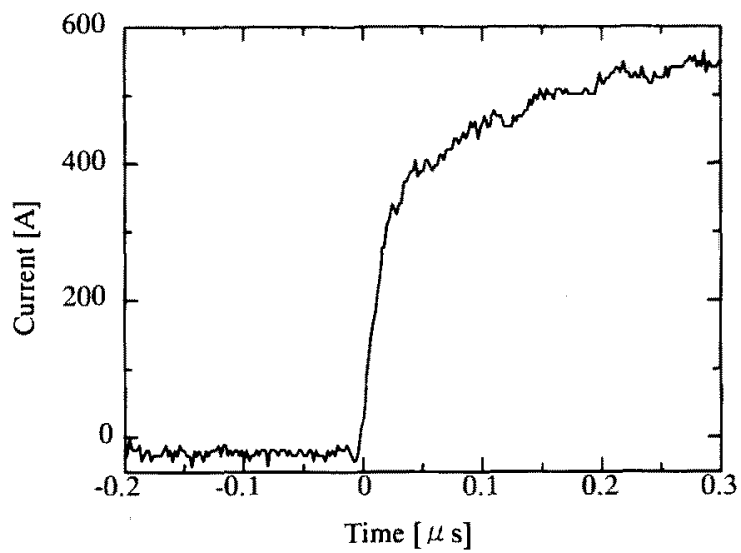

図 2 故障点で発生した地絡電流波形

Fig. 2 Current waveform at fault point.

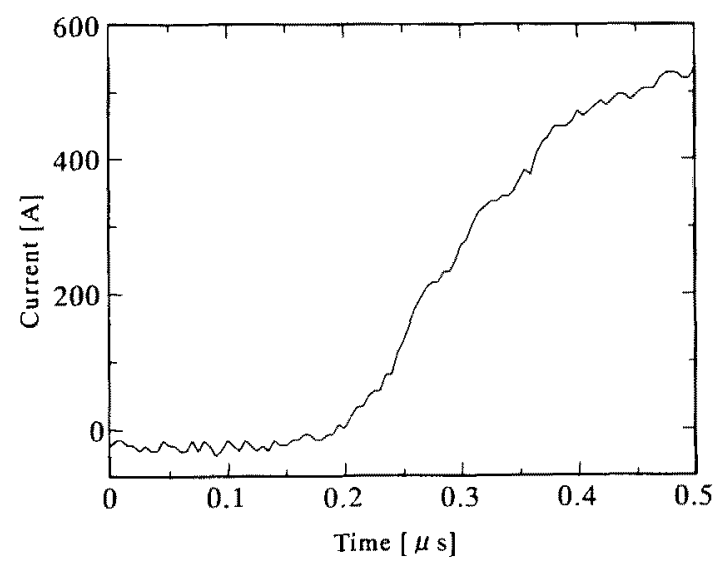

図 3 電力ケーブル中を $125 \mathrm{~m}$ 伝投した波形

Fig. 3 Current waveform passed $125 \mathrm{~m}$ in XLPE (cross-linked polyethylene) cable. 


\section{2 . 2 到来時刻の決定法}

故障点で発生した地絡電流波形は、模擬実験を行った 結果（図 2)、立ち上がり時間が 200ns〜300ns の非常 に急峻なものであると考えられるが、ケーブル中を伝搬 していくうちにケーブル自身の周波数特性の影響を受 け、観測点では鈍った波形となってしまう（図 3 )。こ のため、到来波形の時間差から故障点を特定する本手法 では、検出されたサージ波形のどの位置を到来時刻と定 義するかで故障点の位置測定精度に大きな影響を与え る。そこで、いくつかの到来波形からの到来時刻決定法 を考案し、どの手法が最も精度良く決定できるかを調べ た。

\subsection{1 微分方式}

これは、波形の変化量が最大となる点をサージ波形の 起点とする手法である。ディジタル信号に対しては、隣 り合う 2 点の差分をとることによりこれが寒現できる ため、単純なアルゴリズムで実現が可能となる。

\subsection{2 クロス点方式}

これは、サージ波形があるしきい值を超えた点を到来 点とする方式である。今回、しきい值としては波形が到 来する以前のノイズの最大值の 2 倍の值を用いた。

\subsubsection{2 点直楾方式}

これは、波形上の2 点を直線で結び、その直線が時間 軸之交わる点を到来点とする方式である。しかし、波形 上のどの 2 点を用いるかという問題が生じる。

そこで今回は、到来サージ波形のピーク值の $10 \%$ 加ら $90 \%$ までの点を $10 \%$ 間隔で求め、2 点が共にピーク値の $50 \%$ 超えるケースを除いた全ての組み合わせで到来 時刻を計算して度数分布を調べ、最も頻度の高い階級の 中央値を採用した。

\section{2.4 最小 2 乗直線方式}

この方式は 2 点直線方式と同様に、サージ波形からあ る直線を決定し、その直線が時間軸亡交わる時刻を到来 時刻とする方式である。ただ、直線の决定法としては少 しでも多くの波形の情報老用いるように、サージ波形の ある区間内のデータを用いて最小 2 乗法で直線近似を 行った。このデータ区間としては 2 点直線方式と同様の 方法を用い、得られた複数の到来時刻より、2 点直線方 式で採用した方法と同じ統計的処理を行い到来時刻を 決定した。

\section{3. 周波数特性補正による事故点測定精度向上}

本方式では、故障点と観測点の距離が長くなるほど、 ケーブルの周波数特性の影響を受け、観測点でのサージ 波形の立ち上がり部分が鏈ってしまうため、到来時刻の
決定が難しくなり、故障点測定精度が悪化してしまう。

そこで、ケーブルの周波数特性による鈍りに対する補 正を行い、サージ波形の立ち上がり部分を急峻化するこ とで到来時刻をより明確にし、故障点测定精度を向上す る事が可能かどうか検討を行った。

\section{1 波形急峻化の原理}

故障点で発生した急峻な地絡電流波形はケーブルの 周波数特性の影響を受けて、観測点では鈍った波形とな ってしまう。すなわち、故障点での地絡電流波形のスペ クトルを $S_{i}(\omega)$ 、故障点から観測点までのケーブルの周 波数特性を $H(\omega)$ 、観測点での電流波形のスペクトルを

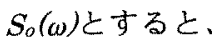

$$
S_{o}(\omega)=S_{i}(\omega) \times H(\omega)
$$

で表される。一般的にケーブルの周波数特性は高周波が 減衰する低域通過フィルタ型の周波数特性であるので、 ケーブルを伝搬する距離が長いほど、電流波形中の高周 波成分が失われ、高周波成分が多く含まれるパルスの立 ち上がり部分が失われ波形が鈍る。そこで、このケーフ ルの逆特性を持つディジタルフィルタを設計し観揤波 形を通す。

$$
S_{i}(\omega)=S_{o}(\omega) \times H^{-1}(\omega)
$$

ここで $H^{-1}(\omega)$ はケーブルの周波数特性の逆特性を表す。 もしも理想的な逆特性が得られれば、(3)式に示される
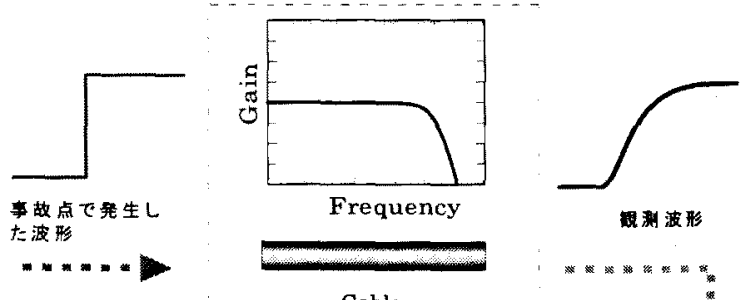

Cable

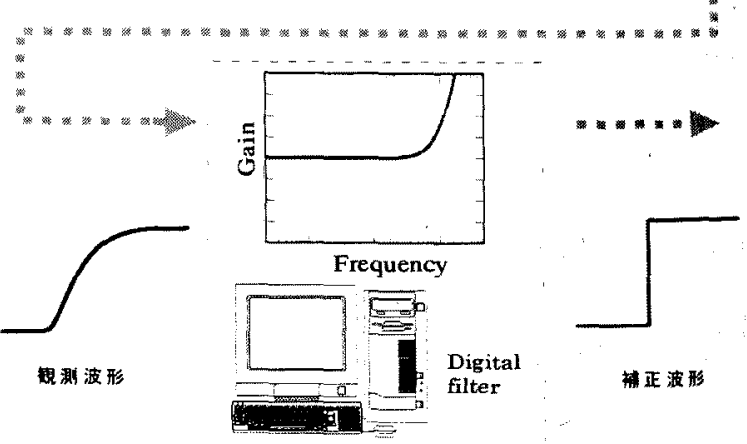

図 4 周波数特性の補正

Fig. 4 Frequency compensation of a pulse passed through a cable. 
ようにケーブル伝搬によるスペクトルの減衰分が相殺 され波形の鈍りは完全に補正され、事故点で発生した サージ波形が再現される(図 4)。しかし、ケーブルの 周波数特性は一般に周波数が高いほど減衰が大きくな るので、それを補正する逆特性は一種の微分特性を持っ た增幅器となり、雑音增幅器となるおそれがある。そこ で、適当な周波数で補正を打ち切ることが必要である。 なお、この様な任意の周波数特性を持った逆フィル夕は 周波数サンプリング法で設計されたディジタルフィル タにより実現可能である。

又、ディジタルフィルタを設計するためには、伀搬し てきた距離に対応するケーブルの周波数特性 $H(\omega)$ 必 要となるが、その周波数特性はケーブルの伝搬距離に依 存するため、伝搬してきた距離を求めるために行う補正 にも距離情報が必要になるという矛盾が生じる。

そこで、任意の距離を伝搬したサージ波形をシミュレ 一ションにより予め求めておき、その波形から任意の距 離における立ち上がり時間を調べた。こうして得られた 伝搬距離と立ち上がり時間との関係を用いて、観測され たサージ波形の立ち上がり時閒からおおよその伝搬距 離を求め禣正に用いる距離情報を得た。

\section{2 到来サージ波形の補正}

補正を行うにあたって、予め伝搬距離とサージの立ち 上がり時間の関倸を調べておく必要がある。そこで、シ ミュレーションを使って各伝搬距離での波形を模擬し、 その立ち上がり時間から、サージ波形の立ち上がり時間 と距離のおおよその関係を求めた。長さ $85.3 \mathrm{~m}$ の電力 ケーブルの周波数特性をネットワークアナライザ (HP8751A)で測定し、その結果を用いて伀搬波形のシミ エレーションを行い、伀搬距離と立ち上がり時間の関係 を調べた。但し、立ち上がり時間としては、到達波形の ピーク值の $10 \%$ から $50 \%$ に達するまでの時間とした。 これは、 $50 \%$ 超える部分には、ケーブルの接続部等か

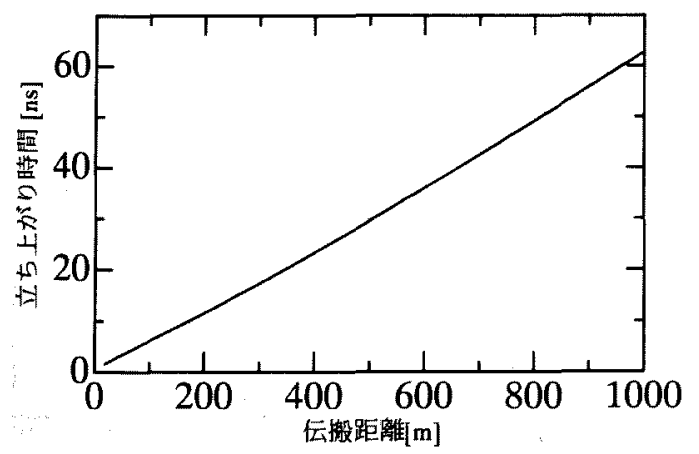

\section{図 5 公猳距離とサージ波形の立ち上がり時間の 䦛係}

Fig.5 Dependence of the rise time of the surge to the propagation distance in the cable.

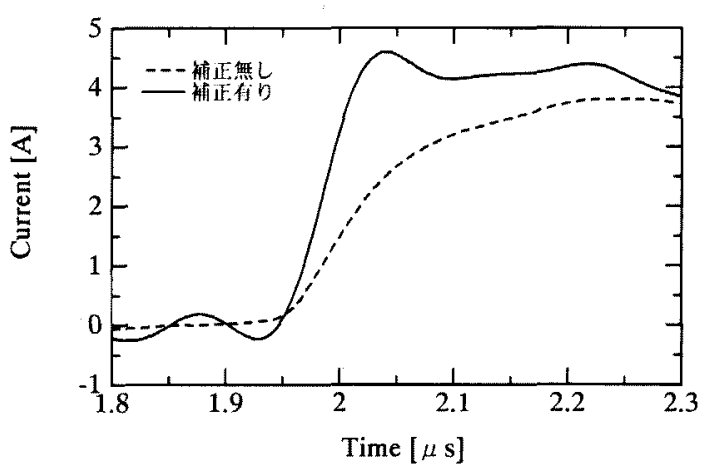

図6 周波数特性を㭪正した波形の一例

Fig. 6 A waveform after the frequency compensation.

らの反射波の影響をうけている場合があるからである。 その結果、図 5 に示すように立ち上がり時間上距離はお よそ直線の関係があることがわかった。

R.L.Wigington らの研究では、ケーブルを伝搬するパ ルスの立ち上がり時闇は伝搬距離の 2 乗に比例するこ とが示されている(5)。しかし、Wigingtonらは観測点 では観測できない入力波形の振幅を使って立ち上がり 時間を定義している。我々は上述のように観測点での観 测波形のみで立ち上がり時問を定義しており、その場合 は図 5 のようにおよそ比例の関係となることが示され る(8)。これは上記の定義の立ち上がり時間を用いる場合 にケーブルに一般的に成立する関係である。

この立ち上がり時間と距離の関係式を用いておよそ の伀搬距離を推定し、その距離に対応するケーブルの周 波数特性の逆特性を掛け合わせ、到来サージ波形の補正 を行う。

以上のような方式で設計されたディジタルフィルタ を用い、到来サージ波形の補正を行い急峻化した結果の 一例を図6に示す。補正フィル夕には測定された周波数 特性に基づき、周波数サンプリング法で設計された 2047 次のF I R (Finite Impulse Response) ディジタ ルフィルタを用いた。ただし、前述のようにケーブルの 周波数特性の完全な逆特性ではなく、ケーブルの振幅特 性が-20dBの範国まで補正を行った。それ以上は $\mathrm{S} / \mathrm{N}$ 比 が低いので補正は行わず、限定した笧囲のみ補正するこ とで雑音の影響を最小限に抑えた。補正の結果、波形の 最大変化率は $37.5[\mathrm{~A} / \mu \mathrm{s}]$ から $80.6[\mathrm{~A} / \mu \mathrm{s}]$ へと 2 倍以上 改善されている。

なお、以上の理論浊立した 1 本のケーブルしか存在 しないとした単純化されたモデルである。現実的には電 カケーブルは 3 相クロスボンド方式等で敖設され、心線 とシース間以外にも他のケーブルや大地との結合によ り多数のモ一ドが存在する。それぞれのモード每に周波 数特性や伝搬速度は異なり、一般に到達波形は非常に 


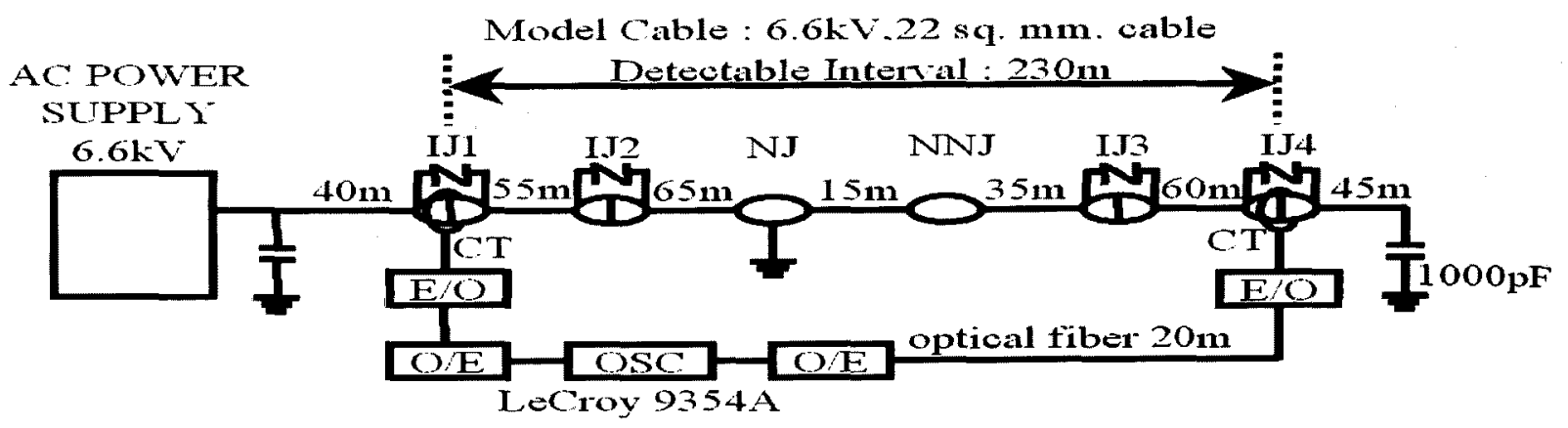

NJ : Nomal Joint

C.T : PEASON $110 \mathrm{~A}$

NNJ : Non-grounded Normal Joint

E/O: Tektronix A69T03

IJ : Insulating Joint

O/E: Tektronix A69R03

\section{因 7 事故点率点実略の榑成図}

Fig. 7 Experimental setup.

複雑なものとなる。しかし、その様な場合でも電流の三 相和を用いると比較的単純な波形が得られる(3)。又、周 波数特性の逆特性もおおよその距離情報から見積もれ る様にそれ程高い精度は補正には要求されない。したが つて、パルスの伀搬速度の情報を予め取得しておけば、 現実的なシステムに対しても本方式は適用可能上考元 られる。それでも、クロスボンドの接続点での反射の影 響・アレスタ等の非楾形部品の影響等、現実的なシステ ムでは本方式での位置測定精度に影響を与えうる要因 が数多く存在する。そこで、実際に現害的な電力ケーブ ルシステムを模擬した模擬線路を敷設し、それを使って 本方式の測定精度がどの程度になるのかを実験的に調 ベた。

\section{4.模擬地絡を用いた電流サージ検出方式による 事故点標定実験}

\section{1. 実験方法}

これらの到来時刻決定法及び周波数特性補正の信号 処理の特失を実際に調べるため、 $\mathrm{AC} 6.0 \mathrm{kV} の$ 電圧を印 加し模擬事故点標定実験を行った。その実験配置図を図 7 に示す。

全長 $315 \mathrm{~m}$ 、検出区間 $230 \mathrm{~m}$ の $6.6 \mathrm{KV}$ 級 $22 \mathrm{~mm}^{2}$ の電 力用 $\mathrm{CV}$ ケーブルを 3 相クロスボンド方式で敖設し、事 故による地絡を模擬するため、事故相にのみ $\mathrm{AC} 6.0 \mathrm{kV}$ を印加し、気中ギャップを用いて模擬地絡を行った。各 絶緑接続部には酸化覀鉆形避雷器 (アレスタ) が橋絡非 接地方式で取り付けてある。図中の NJと NNJ はそれ ぞれ大地に接地されたクロスボンドの接続部と非接地 の接続部であり、IJは絶緑接続部である。模擬地絡は $\mathrm{AC}$ 電圧のほほピーク時に発生するように調節し、この 時生じたサージ電流を IJ1とIJ4の地点において、各々 ーブルのクロスボンド接続線とアレスタに流れる電流 として電流センサ PEASON2877 用いてそれぞれ観
測した。信号処理にはそれら三相の電流の和を計算した ものを用いた。三相和を用いるのは大地帰路モード等の 影響をできるだけ軽減するためである(3)。模擬事故点は 位㯰を変え 7 籄所で赛験を行った。一例として、IJ3 事故点としてIJ1 とIJ4の地点で観測された到来サージ と、その周波数特性の補正を行った結果を図 8 に示す。 二つのサージの到来時間差より(1)式で事故点の位置を 推定する。

\section{2 各到来時刻決定法による位置標定誤差}

複数地点の模擬地絡実験で得られた各部電流波形に $4 \supset$ 到来時刻決定法を用いて事故点標定を行い、IJ1 から事故点までの距離と事故点標定誤差の関倸を求め た。各事故点での標定結果と正しい位置との間の標定誤 差を測定した 7 簓所について求め、二乗平均して平均二 乗誤差とし、検出区間である $230 \mathrm{~m}$ で割って求めた相対 誤差の比較を行った結果を図 9 に示す。クロスボンド

接続線電流とアレスタ流入電流及び両者の和のどの 電流を測定すべきかという点に関しては、クロスボンド

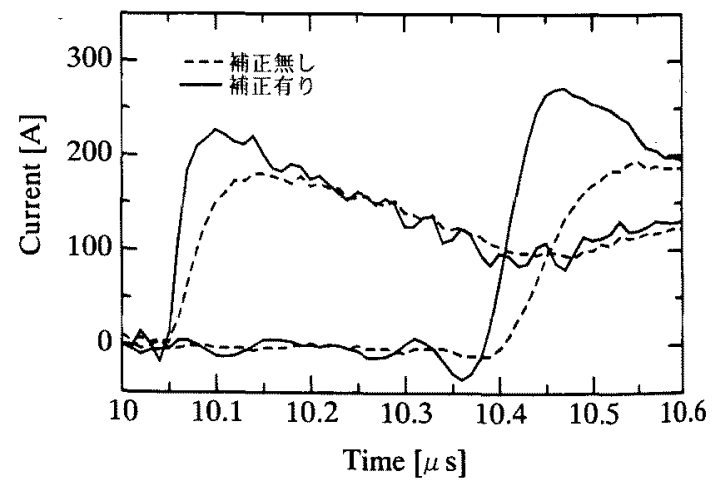

図 8 実睃で覞測された到来サージの一例

Fig.8 A wave form of the arrived surge in the experiment 


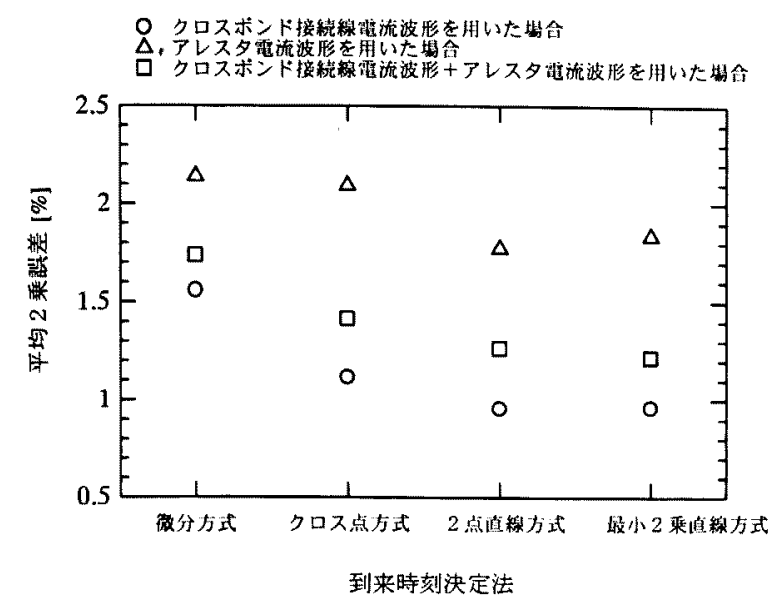

図 9 各種到来時刻決定法による誤差の量い

Fig. 9 Averaged square error of each method.

接続楾電流を用いた結果が最も精度が良くなった。これ はアレスタに流れる電流波形がクロスボンドを流れる 電流よりも鈍りが大きいことの影響である。又、どの方 式でも $3 \%$ 以内の精度で事故点を求めることができた が、最も良かったのは 2 点直線方式と最小二乗直線方式 であった。

\section{3 周波数特性の補正を行った埸合の位置 標定誤差}

さらに、サージ波形に対し前記の補正を行い波形を急 峻化した波形に、各到来時刻決定法を用いて事故点標定 を行った。

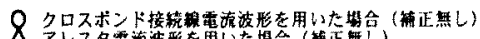

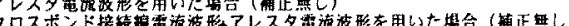

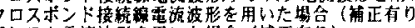

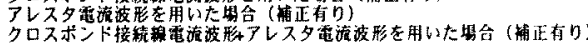

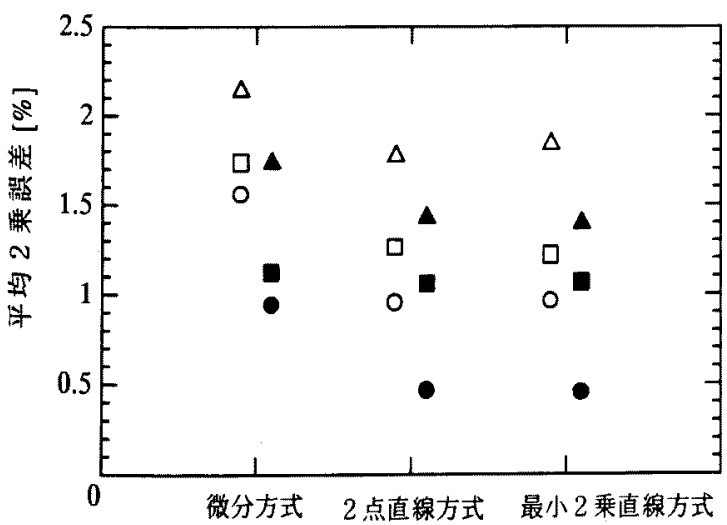

到来時刻決定法

图 10 載正を行った場合の各種到来時刻決定法による 諆差の遧い

Fig. 10 Averaged square error of each method with the frequency compensation.
クロス点方式は、ノイズを増幅する性質を持つ逆フィ ルタの影響で測定不能となつたが、他の三つの到来時刻 決定法については、補正波形を用いることで測定精度が 向上した結果が得られた。補正の結果、伝搬距離が伸び 波形の鈍りが大きくなっても、補正を行わない場合と異 なりそれほど精度が悪化しない結果が得られた。それら について平均 2 乗誤差を用いて比較した結果を図 10 に示す。この結果より、最も誤差が小さいのはクロスボ ンド線電流に補正波形を用いて 2 点直線方式または最 小 2 乗直線方式で求めた場合であり、測定精度約 $0.5 \%$ が得られた。

\section{5.サージ波形の伝搬速度に対する検討}

本手法では、(1)式を使って事故点の位置を計算する。 したがって、予めケーブルを伝搬するパルスの伝搬速度 $\mathrm{v}$ を求めておく必要がある。伝搬速度を求めるにもいく つかの手法があるが、我々は位相特性の傾きを利用して 求めた。これは赛験的に伝搬速度を求める手法が、前述 の波形鈍りの影響で精度が悪いためである。雑音の影響 が強く出る振幅特性が- $60 \mathrm{~dB}$ を超える点までの位相特 性のデータを最小 2 乗法で直線近似し、その傾きより位 相速度を求めているが、この速度は、位䈯測定精度に直 結するのでその精度が問題となる。しかし、そうして計 算された伝搬速度では、まだ不正確であるという結果が 図11に示すように得られた。

図 11 は位相速度を光速に対する比である速度係数 で表し、一例として、微分方式の場合の誤差が速度係数 を変化させた場合にどの様に変化するかを求めたもの である。その結果、ある速度係数で極小值をとるのであ るが、それは上記の位相特性の傾きより求めた速度保数 0.509 という值とは異なる 0.47 で極小值をとった。こ れは、前記の手法では位相速度を求めるのに速度は周波 数によらず一定として求めたが、現実のケーブルの位相 特性は直線でなく、よく知られている様にその傾きの值

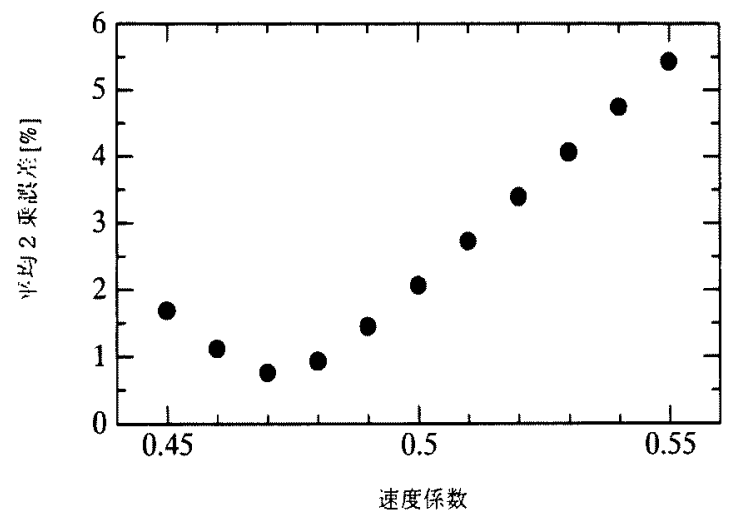

図 11 平均二乗誤差の速度保数依存性

Fig.11 Dependence of the velocity factor of the power cable to the frequency. 


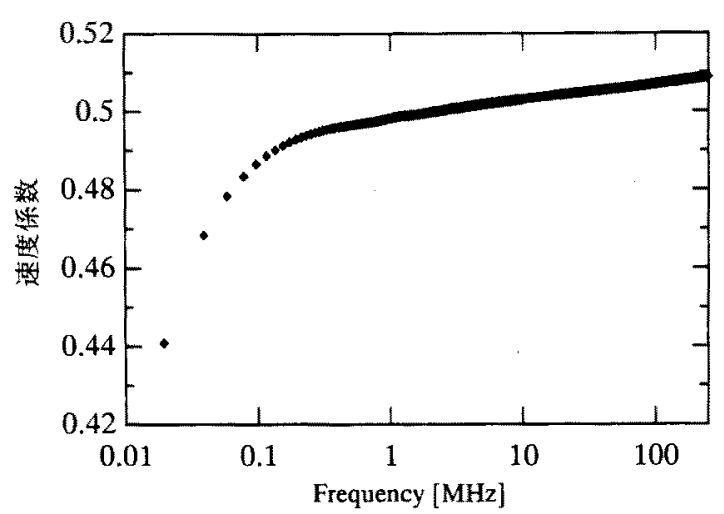

図 12 電力ケーブルの速度俰数の周波数依存性

Fig. 12 Dependence of the averaged square error to the velocity factor

である速度も周波数によって変化するためである。そこ で、本実験に用いた電力ケーブルの位相特性を各周波数 毎に微分して、周波数に対する速度保数の依存性を求めた のが図 12 である。速度倸数は特に周波数が低い所で大き く変化する。実際の波形も、この伝搬速度の周波数に上る 違い（分散性）の影䇺を受けている。0.509という值は単 純に各周波数の算術平均をとることに対応する。

しかし、現実の到来するサージ波形は、前述のように ケーブルの周波数特性のため、伝搬の過程で高周波成分 が失われ、1 10MHz 程度以下の低周波成分が主なも のとなつている。実際に、120m 電力ケーブルを伝搬し た波形をFFT (Fast Fourier Transform) でスペクトル 解析した結果が図 13 である。このデータも図 7 の測定 系と同じもので測定した。

周波数に対する算術平均では、到達波形中にはほとん ど存在しない $1 \mathrm{MHz}$ 以上の成分の影響が相対的に大き くなるので、到達波形を構成しているスペクトル成分の 大きさに基づき重み付けして速度係数を求めることと

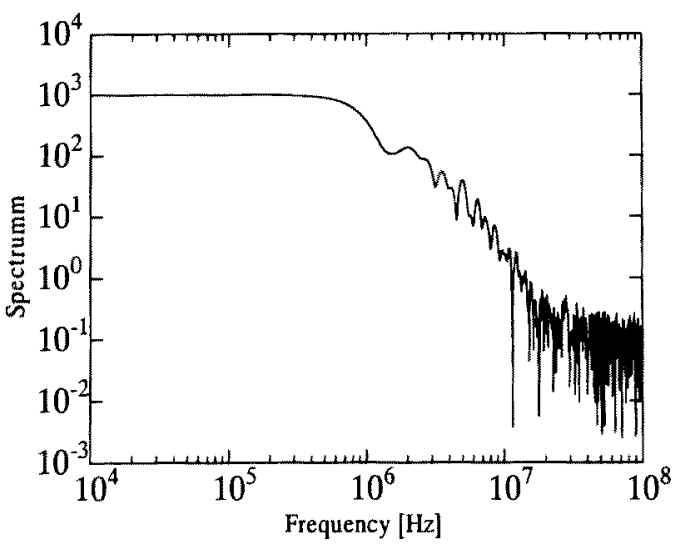

図 13 到来サージ波形の周波数スペクトル

Fig.13 Frequency spectrum of surge-waveform passed $120 \mathrm{~m}$ in XLPE cable.
した。すなわち、到達波形のスペクトルを $s(\omega)$ 、各周 波数での速度係数 $v(\omega)$ として、重み付け平均された速 度兹数 $v_{p}$ を求めた。

$$
v_{p}=\frac{\int v(\omega) s(\omega) d \omega}{\int s(\omega) d \omega}
$$

実際にはケーブルは線形システムと考えられるので、 各周波数成分がそれぞれの速度で伝洀し観測点でそれ らが合成され波形が形成される。したがって、（4）式 は周波数成分の中で相对的に大きな成分がより多く全 体としての速度に影響を与えるという仮定をしている ことに対応する。その結果の重夕付け平均された速度係 数 $v_{p}$ は 0.475 となり、図 11 と比較してもかなり妥当 な速度倸数の值を位相特性の測定結果より本実験の場 合は見積もることができた。厳密には到来サージ波形の スペクトルにも伝搬距離依存性があるのだが、それはど 大きなものではないので、実用的な伝搬距䧶の䉇囲内で あれば目安の値として利用しうると考えられる。

以上は、単絓化された同軸モードでの議論であるが、 現夷には速度の異なる多くのモードが存在すると共に、 実際の伝搬速度はケープルの教設状沉・付帯設備等によ つても变化する。しかし、本実験の様に電流の三相和を 用いる場合は、同軸モードが主な成分となり、この様な 単純化されたモデルでの近似が比較的妥当なものとな る。なお、より定量的に倣密な議論をする為に牥、本研 究はある一つのシステムについて夷験的に検討した結 果であるので、様々な異なった条件での実験を行うこと、 実際に敷設された状況で位相特性を測定した結果と比 較すること等、実際的な状況でのさらなる実験・検証が 必要と考光られる。

\section{6.まとめ}

本論文では、事故点で発生する地絡電流波形の到来时 間差を用いた事故点探查方式である電流サージ検出方 式での測定精度改善のため、いくつかの信号処理を導入 することを検討した。

電力ケーブルの周波数特性のため鈍ってしまった波 形の到達時刻の決定法をいくつか検討し、波形上の 2 点 を直線で結びその直線が時間軸と交わる点を到来点と する方式や、立ち上がりを最小二乗法で求めた直線で近 似しその直線が時間軸と交わる点を到来点とする方式 の精度が良好であることを確認した。

電力ケーブルの周波数特性の影響で鈍ってしまった 波形を、ディジタフィルタを用いた逆フィルタによつ て補正することで、さらに測定精度が改善できることを 明らかにした。

電流サージ検出方式では、事前に必要な情報である波 形の伝搬速度が直接測定精度に直結するが、それをケ一 ブルの位相特性から求める手法について検討した。 
さらに、これら提案の手法が害際の条件でどれだけの 精度改善につながるかを定量的に調べるため、実際に実 機の $1 / 10$ スケールの 3 相クロスボンド方式の模擬 線路を敷設し、模擬的な事故点からのサージ伝搬の時間 差から事故点標定を行い各手法の得失を調べた。

その結果、ディジタルフィルタを用いた波形の補正及 び鈍った波形の到来時刻決定法の改善、サージの伝搬速 度の决定法についての改良等で、位置測定精度が改善で きることを実験的に確認した。そして、それらの信号処 理の導入により $0.5 \%$ 程度の位置測定精度が達成できる 可能性を示した。

(平成 12 年 02 月 28 日受付, 平成 12 年 06 月 21 日再 受付)

$$
\text { 文 献 }
$$

（1）速水敏幸：「CVケーブル」コロナ社(1986)

(2) 飯塚喜八郎監修:「電力ケーブル技術ハンドブック」 電気書院 (1989).

(3) T. Matsumoto, M. Yamada , H. Nakamura, H. Yasui, Y. Maruyama, T. Kawamoto and H.Inuzuka: "Real Time Fault Location System for Cross Bonded Cable System", Proc. 10th Int. Symp. on High Voltage Eng., 6, pp.352-355, (1997).

（4）中村秀人、吉田俊朗、丸山義雄、松本隆宇: ”地中送 電線路用事故点標定システム”，古河電工時報，102, pp.93-98, (1998).

(5) R.L.Wigington and N.S.Nahman: "Transient analysis of coaxial cables considering skin effect", Proc. IRE, 45, pp.166-174, (1957).

(6) Ola Brein and Inge Johansen: "Attenuation of traveling waves in single-phase high-voltage cables", Proc. IEE ,118, pp.787-793, (1971).

（7）松本隆宇、河本映、犬塚博、坂本俊貴：「サージ検出 方式故障点位置評定の位置精度に関する一考察」平 7 電気学会全大, No.1736, (1995).

（8）井上剛、仲山正樹、犬塚博、松本隆宇：「ケーブル を伝搬するパルスの立ち上がり時間の距離依存性」 平 10 電気学会全大, No.1712,(1998)

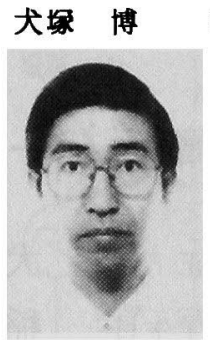

（正員）1957 年 11 月 21 日生まれ。1985 年 3 月名古屋大学大学院博士課程修 了、同年 4 月より同大学工学部助手、 1990 年 4 月より静岡大学工学部助教 授、現在に至る。工学博士。電力ヶ ーブルの測定法・プラズマ計測・非 定常スペクトル解析等のディジタル 信号処理を応用した計測法の研究に 従事。

井上刚（非会員）1972 年 4 月 24 日生まれ。1998

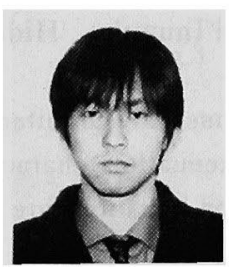
年 3 月静岡大学大学院博士前期課程 修了、同年 4 月松下技研株式会社入 社、現在、情報・ネットワーク研究 所所属。在学中は電力ケーブルの故 障点探査法の研究を行う。現在は音 声信号処理の研究に従事。

仲山正樹 (非会員) 1974 年 12 月 19 日生まれ。

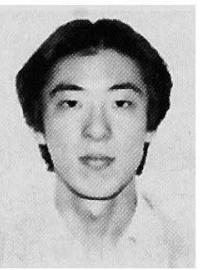
1999 年 3 月静岡大学大学院博士前期 課程修了、同年 4 月日本電気移動通 信株式会社入社、現在に至る。電力 ケーブルの故障点探査法の研究に従 事。

松本隆宇（正員）1952 年 1 月 16 日生まれ。1982

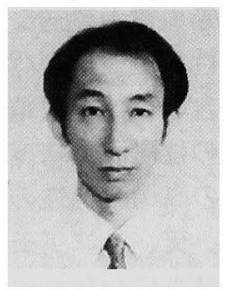
年 3 月東京大学大学院博士課程修了。 同年 4 月より茨城大学工学部助手、 1984 年 4 月より静岡大学工学部助教 授、現在に至る。この間、1991 年 4 月から 1992 年 8 月までスイス連邦 工科大学客員教授。工学博士。主と して、高電圧計測とその応用、放電 現象の研究に従事 